\title{
HUBUNGAN POLA ASUH DAN EKSPRESI EMOSI KELUARGA DENGAN KEKAMBUHAN PASIEN SKIZOFRENIA DI RUMAH SAKIT JIWA MENUR SURABAYA
}

\author{
Lestari Handayani dan Desi Nurwidawati \\ Program Studi Psikologi Universitas Negeri Surabaya
}

\begin{abstract}
Schizophrenia is classified in severe mental disorders so that the possibility to recover from it is fairly minimal. Based on a study, 80\% of schizophrenic patients experienced a relapse from schizophrenia and only about 20\% of patients declared recovered on pre-morbid level (Arif, 2006). Many cases of relapse occurred when the patient returned to their family. Some studies suggest that the factor of interaction patterns within the family, such as parenting and emotional expression among the members of family, leads the patients to relapse. This study aims to determine the correlation between parenting and family emotional expression to the relapse of schizophrenic patients of Menur Mental Hospital, Surabaya. This study used a quantitative approach with a correlation method. The samples were 65 families of patients with schizophrenia who were treated at the Menur Mental Hospital, taken by purposive sampling technique. 35 samples are famillies of hospitalized patients and 30 samples are famillies of outpatient. Data analysed using binary logistic. The correlation between the variables measured using significant value of $p<0.05$ and the Odds Ratio (OR) with $95 \%$ Constant Interval (CI). The results shows a significant value of constant is 0.002 , a significant value of parenting is 0.001 and significant value of family emotional expression is 0.002 . It means that there is a correlation between parenting and family emotional expression with relapse of schizophrenic patients. Family emotional expression was proven as the most variable responsible for the emergence of relapse which affect 16.9 times greater chance of relapse than other variable contribution.
\end{abstract}

Keywords : Parenting, family expressed emotion, relapse, schizophrenia.

\begin{abstract}
Abstrak: Skizofrenia digolongkan dalam gangguan mental berat, sehingga kemungkinan untuk sembuh terbilang kecil. Berdasarkan hasil sebuiah penelitian, sebanyak $80 \%$ pasien skizofrenia mengalami kekambuhan berulang dan hanya sekitar $20 \%$ pasien dinyatakan pulih pada tingkat premorbid (Arif, 2006). Banyak kasus kekambuhan terjadi ketika pasien dikembalikan kepada keluarga. Beberapa penelitian menyebutkan bahwa faktor pola interaksi didalam keluarga menyebabkan kekambuhan, seperti pola asuh dan ekspresi emosi. Penelitian ini bertujuan untuk mengetahui hubungan pola asuh dan ekspresi emosi keluarga dengan kekambuhan pasien di Rumah Sakit Jiwa Menur Surabaya. Penelitian ini menggunakan pendekatan kuantitatif dengan metode korelasional. Sampel adalah 65 keluarga dari pasien skizofrenia yang dirawat di Rumah Sakit Jiwa Menur, diambil dengan teknik purposive sampling. Sebanyak 35 sampel merupakan keluarga dari pasien rawat inap dan 30 sampel merupakan keluarga dari pasien rawat jalan di Rumah Sakit Jiwa Menur Surabaya. Analisis data menggunakan uji regresi logistik biner. Adanya hubungan antara variabel diukur dengan menggunakan nilai signifikan $\mathrm{p}<0,05$ dan Odds Ratio (OR) dengan interval kepercayaan (CI) 95\%. Hasil penelitian diperoleh nilai signifikan konstanta sebesar 0,002, nilai signifikan pola asuh sebesar 0,001 dan nilai signifikan ekspresi emosi keluarga sebesar 0,002 . Hal tersebut berarti bahwa ada hubungan pola asuh dan ekspresi emosi keluarga dengan kekambuhan pasien skizofrenia. Ekspresi emosi keluarga merupakan variabel yang paling berperan terhadap munculnya kekambuhan karena memiliki peluang 16,9 kali lebih besar memunculkan kekambuhan dibandingkan dengan variabel yang lain.
\end{abstract}

Kata kunci : Pola asuh, ekspresi emosi keluarga, kekambuhan, skizofrenia. 
Skizofrenia adalah kekacauan jiwa yang ditandai dengan kehilangan kontak pada kenyataan (psikosis), waham (keyakinan yang salah), halusinasi dan persepsi abnormal yang dapat mengganggu perilaku dan kinerja dalam fungsi sosial (Departemen Kesehatan RI, 1993). Skizofrenia masih menjadi kasus yang paling sering dijumpai di beberapa rumah sakit jiwa. Berdasarkan survey WHO (2004) prevalensi penderita di dunia menunjukkan $1 \%$ dari seluruh penduduk dunia. Insidensi atau kasus yang baru muncul sekitar $0,01 \%$ tiap tahunnya. Jumlah penderita skizofrenia memiliki perbandingan yang sama antara laki-laki dan perempuan. Onset penyakit pada skizofrenia dimulai pada rentang usia 18-25 tahun untuk laki-laki dan pada rentang usia 26-45 untuk perempuan. Jumlah penderita skizofrenia di Indonesia sendiri sebanyak $0,46 \%$ dari keseluruhan jumlah penduduk di Indonesia. Skizofrenia diduga diderita enam sampai sembilan belas orang per seribu penduduk (Permanasari dan Tunggal, 2010).

Gejala skizofrenia dapat menyebabkan penderitanya mengalami penurunan kualitas hidup, sosial, dan pekerjaan. Oleh karena itu, pemberian layanan yang terbatas dan tidak tepat dapat menyebabkan penderita skizofrenia mengalami kecacatan fisik maupun motorik (Lora, dkk, 2011). Kemungkinan pasien skizofrenia untuk sembuh terbilang minim. Menurut Arif (2006), terdapat sebanyak $80 \%$ pasien skizofrenia mengalami kekambuhan secara berulang. Sekitar 25\% pasien dapat dinyatakan pulih dari episode awal dan dapat menjalani fungsinya pada kondisi sebelum munculnya gangguan. Sekitar $25 \%$ pasien tidak menunjukkan perjalanan penyakit yang cukup membaik, akibatnya pasien dinyatakan tidak akan pernah pulih. Sekitar $50 \%$ pasien lainnya ditandai dengan kekambuhan periodik dan ketidakmampuan berfungsi dengan efektif dalam jangka waktu yang lama.
Pasien skizofrenia masih harus memperoleh perawatan yang memadai dari keluarga, baik secara materi, fisik maupun emosional setelah menjalani perawatan di rumah sakit (Gunarsa, 2000). Perawatan orang tua kepada penderita pasien skizofrenia ditunjukkan melalui pola asuh yang diterapkan serta ekspresi emosi yang ditunjukkan selama berinteraksi dengan penderita. Pengasuhan bertujuan untuk memenuhi kebutuhan dasar anak (Wahyuning dkk, 2003). Menurut Titi (dalam Soetjiningsih, 2004) pola asuh harus mencukupi tiga aspek, yaitu asuh, asih, dan asah. Asuh merupakan pemenuhan kebutuhan fisik dan biomedis, asah adalah pemenuhan kebutuhan emosi dan kasih sayang serta asuh yang merupakan pemenuhan kebutuhan akan stimulasi mental.

Sikap dan perilaku keluarga terhadap pasien mencerminkan ekspresi emosi keluarga. Konsep ekspresi emosi keluarga dikembangkan oleh Brown dan Rutter (dalam Lieberman dkk, 2006) untuk menjelaskan alasan mengapa beberapa pasien skizofrenia rawat inap yang memiliki respon positif terhadap obat justru mengalami kekambuhan setelah tidak lama dikembalikan kepada keluarga. Sebuah studi oleh Parker, dkk (1990) tentang pola asuh dan ekspresi emosi keluarga yang diukur menggunakan Parental Bonding Instrument dan Family Camberwell Interview membuktikan bahwa ada kesempatan yang signifikan penderita skizofrenia mengalami kekambuhan. Pada penelitian ini kekambuhan pasien skizofrenia didefinisikan sebagai terulangnya kembali gejala psikotik pada pasien skizofrenia yang menyebabkan rawat inap (Thames, 2008). Pola asuh didefinisikan cara perlakuan orang tua yang diterapkan kepada anak dengan gangguan skizofrenia, merujuk kepada suatu proses interaksi antara pengasuh dengan anak yang diasuh dimana interaksi tersebut mencakup aspek-aspek yang memenuhi 
kebutuhan anak. Menurut Brown \& Rutter (dalam Lieberman, 2006) ekspresi emosi keluarga adalah indeks keseluruhan sikap, dan perilaku yang diekspresikan oleh anggota keluarga terhadap anggota keluarga yang mengalami gangguan skizofrenia.

Penelitian tentang hubungan pola asuh dan ekspresi emosi keluarga dengan kekambuhan masih jarang dilakukan khusunya di Surabaya. Karena itu memahami hubungan pola asuh dan ekspresi emosi keluarga dengan kekambuhan pasien skizofrenia di Surabaya diharapkan dapat memperluas ilmu pengetahuan dan memberikan informasi kepada pihak-pihak yang berkaitan dengan pasien, terutama keluarga untuk merencanakan program perawatan sebagai upaya peningkatan kualitas hidup pasien skizofrenia.

\section{METODE}

Penelitian ini menggunakan pendekatan kuantitatif dengan metode deskriptif korelasional. Analisis statistik deskriptif digunakan untuk memperoleh gambaran tentang karakteristik subjek penelitian berdasarkan jenis kelamin, usia, tingkat pendidikan, pekerjaan, agama, hubungan keluarga dengan subjek, dan jumlah anggota keluarga. Sedangkan analisis korelasional digunakan untuk mengetahui hubungan variabel pola asuh dan ekspresi emosi dengan kekambuhan pasien skizifrenia.

\section{Sampel}

Subjek penelitian adalah keluarga dari pasien dengan diagnosis skizofrenia sesuai dengan Pedoman Penggolongan Diagnosis Gangguan Jiwa (PPDGJ III) dan menjalani rawat inap maupun rawat jalan di Rumah Sakit Jiwa Menur Surabaya. Penentuan sampel menggunakan teknik purposive sampling. Kriteria subjek penelitian adalah keluarga pasien skizofrenia yang berdomisili di Surabaya dan berinteraksi setiap hari dengan pasien. Jumlah subjek dalam penelitian adalah 65 keluarga yang terdiri dari 35 sampel merupakan keluarga dari pasien rawat inap dan 30 sampel merupakan keluarga dari pasien rawat jalan di Rumah Sakit Jiwa Menur Surabaya.

\section{Teknik Pengumpulan data}

Teknik pengumpulan data dilakukan melalui penyebaran kuesioner, dimana sebelumnya responden diberikan lembar informed consent. Instrumen penelitian menggunakan skala pola asuh yang disusun berdasarkan aspek-aspek menurut Titi (dalam Soetjiningsih, 2004) yang menyatakan bahwa pola asuh harus mencukupi tiga aspek, yaitu asuh, asih, dan asah. Skala ekspresi emosi keluarga disusun berdasarkan aspek-aspek menurut Brown dan Rutter (Lieberman dkk, 2006) yang mendefinisikan ekspresi emosi mencakup critical comment, emotional overinvolvement dan hostility. Ekspresi emosi keluarga yang tinggi mengarah pada peluang munculnya kekambuhan. Hasil uji validitas dan reliabilitas instrumen adalah sebagai berikut :

Tabel 1. Hasil uji validitas dan reliabilitas instrumen

\begin{tabular}{lcc}
\hline \multicolumn{1}{c}{ Skala } & $\begin{array}{c}\text { Koefisien Validitas } \\
\text { Aitem }\end{array}$ & $\begin{array}{c}\text { Koefisien } \\
\text { Reliabilitas }\end{array}$ \\
\hline Pola Asuh & $0,300-0,719$ & 0,932 \\
$\begin{array}{l}\text { Ekspresi Emosi } \\
\text { Keluarga }\end{array}$ & $0,308-0,723$ & 0,943 \\
\hline
\end{tabular}

\section{Analisis Data}

Analisis data menggunakan analisis regresi logistik biner yang bertujuan untuk mengetahui hubungan antara pola asuh dan ekspresi emosi keluarga dengan kekambuhan pasien skizofrenia serta dari hubungan tersebut diperoleh probabilitas 
munculnya kekambuhan akibat pengaruh pola asuh dan ekspresi emosi keluarga. Analisis data dilakukan dengan bantuan SPSS (Statistical Package for Social Science) 17.0 for windows.

\section{HASIL DAN PEMBAHASAN}

Selama pengumpulan data diperoleh subjek penelitian sejumlah 65 keluarga pasien skizofrenia yang menjadi responden, namun hanya 60 orang keluarga pasien skizofrenia kooperatif selama proses penelitian. Sebanyak 30 responden merupakan keluarga yang memiliki anggota keluarga diagnosis skizofrenia yang menjalani rawat inap lebih dari dua kali dan 30 responden lainnya memiliki anggota keluarga diagnosis skizofrenia yang menjalani rawat jalan, dimana pasien belum pernah menjalani rawat inap atau pasien telah menjalani rawat inap kurang dari dua kali. Keseluruhan pasien skizofrenia yang merupakan anggota keluarga dari responden memiliki rentang usia antara 20 sampai 45 tahun. Berikut adalah rincian data status perawatan subjek penelitian yang diperoleh dari data rekam medik Rumah Sakit Jiwa Menur Surabaya yang terlihat pada Tabel 2.

Tabel 2. Karakteristik Subjek Berdasarkan Status Perawatan

\begin{tabular}{ccc}
\hline $\begin{array}{c}\text { Frekuensi } \\
\text { Rawat Inap }\end{array}$ & $\begin{array}{c}\text { Jumlah } \\
\text { Pasien }\end{array}$ & $\begin{array}{c}\text { Status } \\
\text { Perawatan }\end{array}$ \\
\hline $0-2$ & 30 & Rawat Jalan \\
$3-5$ & 6 & Rawat Inap \\
$5-8$ & 19 & Rawat Inap \\
$8-10$ & 14 & Rawat Inap \\
$>10$ & 9 & Rawat Inap \\
\hline Total & 65 & - \\
\hline
\end{tabular}

Subjek penelitian memiliki variasi yang berbeda-beda berdasarkan jenis kelamin, usia, tingkat pendidikan, pekerjaan, agama, jumlah anggota keluarga dan status dalam keluarga. Tabel 3. Memaparkan frekuensi variasi subjek penelitian.
Hasil penelitian berdasarkan analisis deskriptif dari dua variabel bebas, yakni pola asuh dan ekspresi emosi keluarga dipaparkan berdasarkan jumlah frekuensi valid $(\mathrm{N})$, nili rata-rata (mean), nilai tengah (median), nilai yang paling sering muncul (mode), standart deviasi, sebaran nilai minimum dan maksimum serta jumlah total dari data yang diperoleh melalui kuesioner yang disebarkan kepada reponden. Hasil analisis deskriptif terlihat pada Tabel 4.

\section{Tabel 3. Frekuensi Variasi Subjek Penelitian}

\begin{tabular}{cc}
\hline Responden & Total \\
\hline A. Jenis Kelamin: Laki-laki & $25(41,67 \%)$ \\
Perempuan & $35(58,33 \%)$ \\
\hline B. Usia: $\geqslant 40$ tahun & $8(13,33 \%)$ \\
$41-60$ tahun & $35(58,33 \%)$ \\
$61-80$ tahun & $17(28,34 \%)$ \\
\hline C. Pendidikan: Tidak Sekolah & $4(6,67 \%)$ \\
SMP & $21(35 \%)$ \\
SMA & $14(23,33 \%)$ \\
Perguruan Tinggi (PT) & $20(33,33 \%)$ \\
Ibu Rumah Tangga & $1(1,67 \%)$ \\
Buruh & $9(15 \%)$ \\
Wiraswasta & $16(26,67 \%)$ \\
Lain-lain & $6(10 \%)$ \\
\hline D. Pekerjaan: Tidak bekerja & $13(21,66 \%)$ \\
Kristen & $58(96,67 \%)$ \\
Katolik & $1(1,67 \%)$ \\
\hline E. Agama: Islam & $1(1,67 \%)$ \\
\hline F. Jumlah Anggota Keluarga: $\leqslant 4$ & $37(61,67 \%)$ \\
& $14(23,33 \%)$ \\
\hline G. Hubungan dengan Pasien: & $9(15 \%)$ \\
Ibu Kandung & $21(35 \%)$ \\
Ayah Kandung & $22(36,67 \%)$ \\
Lain-lain & $17(28,33 \%)$ \\
\hline
\end{tabular}

Tabel 4. Hasil Analisis Deskriptif

\begin{tabular}{crr}
\hline & Pola Asuh & Ekspresi Emosi \\
\hline N Valid & 60 & 60 \\
Mean & 105.63 & 88.33 \\
Median & 102.50 & 92.50 \\
Mode & $90^{\mathrm{a}}$ & 95 \\
Std. Deviation & 18.390 & 17.987 \\
Minimum & 72 & 53 \\
Maximum & 139 & 122 \\
\hline Sum & 6338 & 5300 \\
\hline
\end{tabular}


Data dari skala Ekspresi Emosi Kelurga kemudian dikategorikan ke dalam dua tingkatan, yaitu Ekspresi Emosi Kelurga Tinggi dan Ekspresi Emosi Keluarga Rendah dengan melihat median dari data. Apabila nilai skor lebih besar dari nilai median maka akan dikategorikan tinggi dan diberikan koding 1, sedangkan apabila skor lebih kecil dari nilai median makan akan dikategorikan rendah dan diberikan koding 0 , sehingga diperoleh 30 responden memiliki ekspresi emosi keluarga tinggi dan 30 responden yang memiliki ekspresi emosi keluarga rendah.

Teknik analisis data yang digunakan adalah analisis regresi logistik biner. Analisis regresi logistik biner digunakan sesuai dengan tujuan penelitian, yaitu untuk mengetahui hubungan yang signifikan antara pola asuh dan ekpresi emosi keluarga dengan kekambuhan pasien skizofrenia. Adanya hubungan ditunjukkan dengan menghitung nilai Odds Ratio (OR) dengan interval kepercayaan (CI) 95\% dan tingkat kemaknaan (nilai signifikan) $\mathrm{p}<0,05$. Hasil uji hipotesis ditunjukkan pada Tabel 5. yang membuktikan bahwa variabel pola asuh memiliki nilai signifikan sebesar 0,001 dengan nilai $\operatorname{Exp}(\mathrm{B})$ yang merupakan nilai Odds Ratio (OR) sebesar 0,885. Variabel ekspresi emosi keluarga memiliki nilai signifikan sebesar 0,002 dengan nilai OR sebesar 16,902, sedangkan nilai konstanta dalam analisis ini memiliki nilai signifikan 0,002 . Akibat kedua variabel dan konstanta dalam model regresi logistik ini memiliki nilai signifikan kurang dari $0,05(p<0,05)$ maka hal ini berarti bahwa ada hubungan antara pola asuh dan ekspresi emosi keluarga dengan kekambuhan pasien skizofrenia.

Hasil penelitian ini sesuai dengan penelitian yang dilakukan oleh Helmina (dalam Yanayir, 2012) yang menyimpulkan bahwa ada korelasi antara pola asuh dengan kekambuhan pasien skizofrenia, terutama skizofrenia paranoid. Penelitian lain dilakukan oleh Erlina, Soewadi dan Pramono (2010) juga menyebutkan bahwa pola asuh keluarga patogenik mempunyai resiko 4,5 kali memunculkan gangguan jiwa. Penelitian lain yang sejalan dengan penelitian ini adalah penelitian yang dilakukan oleh Marchira, dkk (2008) tentang ekspresi emosi keluarga pasien dengan kekambuhan penderita skizofrenia di RS. RD. Sardjito Yogyakarta yang menyebutkan adanya korelasi positif antara ekspresi emosi dengan angka kekambuhan pasien skizofrenia. Sejalan pula dengan penelitian Parker, dkk (1990) yang menyatakan bahwa ada kesempatan yang signifikan penderita skizofrenia mengalami kekambuhan diukur dari atribut pengasuhan orang tua dan skor ekspresi emosi keluarga pasien.

Pola asuh yang mewujudkan kedekatan anak dengan orang tua dan ekspresi emosi keluarga rendah dianggap sebagai suatu penerimaan dan dukungan bagi pasien

Tabel 5. Hasil Regresi Logistik Biner

\begin{tabular}{|c|c|c|c|c|c|c|c|c|}
\hline & & & S.E. & Wald & df & Sig. & $\operatorname{Exp}(B)$ & 95\% C.I. \\
\hline \multirow{3}{*}{$\begin{array}{c}\text { Step } \\
1^{\mathrm{a}}\end{array}$} & Pola_Asuh & -.122 & .036 & 11.669 & & .001 & .885 & $.825-.949$ \\
\hline & EE_Keluarga & 2.827 & .923 & 9.383 & & .002 & 16.902 & $\begin{array}{c}2.768- \\
103.191\end{array}$ \\
\hline & Constant & 11.380 & 3.667 & 9.630 & & .002 & 87572.187 & \\
\hline \multicolumn{3}{|c|}{-2 Log Likelihood } & \multicolumn{6}{|c|}{$33.509^{a}$} \\
\hline \multicolumn{3}{|c|}{ Cox \& Snell R Square } & \multicolumn{6}{|c|}{.563} \\
\hline \multicolumn{3}{|c|}{ Negelkerke $R$ Square } & \multicolumn{6}{|c|}{.751} \\
\hline \multicolumn{3}{|c|}{ Overall Percentage } & \multicolumn{6}{|c|}{88.3} \\
\hline
\end{tabular}


skizofrenia. Dukungan merupakan suatu bentuk bantuan yang diberikan kepada individu lain terhadap penderita ketika suatu masalah muncul. Buchanan (dalam Videbeck, 2001) menyebutkan bahwa individu yang sering mendapatkan dukungan emosional dan fungsional terbukti lebih sehat dibandingkan dengan individu yang tidak mendapatkan dukungan. Pola pengasuhan yang mencakup aspek-aspek kebutuhan anak yang diasuh serta ekspresi emosi keluarga yang tidak berlebihan menjadi sebuah respon dari sistem dukungan sosial bagi penderita skizofrenia.

Berdasarkan nilai $\mathrm{OR}>1$ maka variabel yang paling berperan terhadap timbulnya kekambuhan adalah ekspresi emosi keluarga, yakni dengan nilai $\mathrm{OR}=16,902$. Nilai $\mathrm{OR}$ tersebut memiliki arti bahwa kemungkinan pasien skizofrenia dengan keluarga yang memiliki ekspresi emosi tinggi akan mengalami kekambuhan 16,902 kali lebih besar dibandingkan pasien dengan keluarga yang memiliki ekspresi emosi rendah. Sebaliknya, kemungkinan pasien skizofrenia dengan keluarga yang memiliki ekspresi emosi rendah akan mengalami kekambuhan 0,059 (1/16,902) kali lebih besar dibandingkan pasien skizofrenia dengan keluarga yang memiliki ekspresi emosi tinggi.

Relevan dengan pendapat yang dikemukakan oleh Leff dan Vaughn (dalam Brooker, 2008) yang menyebutkan bahwa ekspresi emosi keluarga yang tinggi akan menyebabkan meningkatnya angka kekambuhan. Hal ini berangkat dari alasan Brown dan Rutter (dalam Lieberman dkk, 2006) mengembangkan konsep ekspresi emosi keluarga untuk menjelaskan mengapa beberapa pasien skizofrenia yang dirawat di rumah sakit dan memiliki respon positif atas terapi obat kambuh kembali setelah tidak lama pulang ke rumah.

Nilai OR variabel pola asuh sebesar 0,885 memiliki arti bahwa Apabila pasien skizofrenia memperoleh pola pengasuhan yang mencakup keseluruhan aspek asah, asih dan asuh maka resiko mengalami kekambuhan sebesar 0,885.
Sebaliknya, apabila pasien skizofrenia memperoleh pola pengasuhan tidak mencakup aspek asah, asih dan asuh, maka resiko mengalami kekambuhan sebesar 1,123 $(1 / 0,885)$.

Menurut Gunarsa (2000) keluarga memiliki fungsi dasar seperti memenuhi kebutuhan fisik, memberi kasih sayang, rasa aman, rasa memiliki dan menyiapkan peran dewasa individu kedalam masyarakat. Fungsi dasar keluarga diwujudkan dalam bentuk interaksi antara orang tua (pengasuh) dengan anak (yang diasuh). Kedekatan anak dengan orang tua merupakan salah satu intervensi keluarga dalam upaya memberikan rangkaian terapi untuk mengurangi kekambuhan suatu penyakit. Schafer et al (dalam Scholten, 2007) mengungkapkan bahwa anak-anak yang ditelantarkan oleh orang tuanya baik secara fisik maupun mental dapat meningkatkan resiko munculnya gangguan jiwa.

Nilai Negelkerke R Square sebesar 0,751 atau apabila diubah dalam bentuk prosentase sebesar 75,1\%. Hal ini berarti bahwa pola asuh dan ekspresi emosi keluarga merupakan 75,1\% faktor yang berperan menimbulkan kekambuhan pasien skizofrenia, namun masih terdapat $34,9 \%$ faktor lain yang tidak diteliti dalam penelitian juga turut berperan menimbulkan kekambuhan pasien skizofrenia.

\section{SIMPULAN}

Hasil analisis membuktikan bahwa ada hubungan pola asuh dan ekspresi emosi keluarga dengan kekambuhan pasien skizofrenia di Rumah Sakit Jiwa Menur Surabaya. Ekspresi emosi keluarga merupakan variabel yang paling berperan terhadap kekambuhan, sehingga ekspresi emosi keluarga merupakan faktor yang paling dominan dalam menimbulkan kekambuhan. Ekspresi emosi keluarga tinggi memiliki peluang 16,9 kali lebih besar memunculkan kekambuhan, sedangkan pola asuh yang memenuhi aspek asuh, asih dan asah memiliki 
resiko memunculkan kekambuhan sebesar 0,885 kali. Pola asuh dan ekspresi emosi keluarga merupakan faktor yang memiliki $75,1 \%$ peran dalam menimbulkan kekambuhan pasien skizofrenia, sedangkan masih terdapat $34,9 \%$ faktor-faktor lain yang turut berperan menimbulkan kekambuhan pasien skizofrenia tidak diteliti dalam penelitian.

\section{DAFTAR PUSTAKA}

Arif, S. I. (2006). Skizofrenia: Memahami Dinamika Pasien. Bandung: PT. Refika Aditam

Brooker, C. (2008). Ensiklopedia Keperawatan Churchill Livingstone's Mini Encyclipedia Of Nursing, $I^{s t}$ Edition (Terjemahan). Jakarta : EGC Medical Publisher

World Health Organization (WHO). (2004). The World Report 2004 Statistical Annex (online).www.who.int/entity/whr/2004/an nex/topic/en/annex_2_en.pdf. diakses tanggal 12 Novenver 2012.

Departemen Kesehatan Republik Indonesia. (1993). Pedoman Penggolongan Diagnosis Gangguan Jiwa (PPDGJ). Edisi III. Jakarta.

Erlina, Soewadi, \& Pramono, D. (2010). Determinan Terhadap Timbulnya Skizofrenia Pada Pasien Rawat Jalan Di Rumah Sakit Jiwa Prof. HB Saanin Padang Sumatera Barat. Berita Kedokteran Masyarakat, 26(2), 71-80.

Gunarsa, Y. S. D., \& Gunarsa, S. D. (2000). Psikologi Praktis : Anak, Remaja, dan Keluarga. Jakarta : PT. BPK Gunung Mulya.

Lieberman, J. A., Stroup, T. S., \& Perkins, D. O., (Editor). (2006). The American Psychiatric Publishing Textbook of Schizophrenia. USA :American Psychiatric Publishing, Inc.

Lora, A., Kohn, R., Levav, I., McBain, R., Morris, J., \& Saxena, S. (2011). Service Availability And Utilization And Treatment Gap Schizophrenic Disorders: A Survey in 50 Low and Middle Income Countries (Online). www.who.int/bulletin/ volumes/90/1/11-089284/en/. Diakses tanggal 13 November 2012.
Marchira, C. R., Sumarni P., \& Lusia, P.W. (2008). Hubungan Antara Ekspresi Emosi Keluarga Pasien Dengan Kekambuhan Penderita Skizofrenia Di RS DR. Sardjito Yogyakarta. Berita Kedokteran Masyarakat, 24 (4), 172-175.

Parker, G., Johnston, P., \& Hayward, L..(1990). Prediction of Scizophrenic Relapse Using The Parental Bonding Instrument (online). http://search.ebscohost.com/login.aspx?dir ect $=$ true $\& d b=$ mnh \&AN $=3178613 \&$ sit. Diakses tanggal 24 Oktober 2012.

Permanasari \& Tunggal. (2010). Bicara tentang Jiwa Terpecah (on line). $\mathrm{http} / /$ health.kompas.com/read/2010/10/05 /07092282/Bicara.tentang.Jiwa.Terpecah. Diakses tanggal 13 November 2012

Scholten. (2007). Risk Factor For Schizophrenia. Manchester: University of Manchester.

Soetjiningsih. (2004). Tumbuh Kembang Anak dan Permasalahannya. Jakarta : Sagung Seto

Sugiyono. (2009). Metode Penelitian Kuantitatif, Kualitatif dan $R \& D$. Bandung : Alfabeta

Videbeck. (2001). Buku Ajar Keperawatan Jiwa (Terjemahan). Jakarta : Buku Kedokteran EGC

Wahyuning, Jash, \& Rachmadiana. (2003). Mengkomunikasikan Moral Kepada Anak. Jakarta: PT. Elex Media Komputindo.

Yanayir. (2012). Karakteristik Faktor-Faktor yang Mempengaruhi Terjadimya Skizofrenia di Wilayah Kerja Puskesmas Pembantu Desa Paringan Kecamatan Jenangan Kabupaten Ponorogo (Skripsi). Ponorogo: Fakultas Ilmu Kesehatan Universitas Muhammadiyah Ponorogo. 